\title{
Effect of Gymnema sylvestre on Insulin Receptor (IR) and Proglucagon Gene Expression in Streptozotocin Induced Diabetic Rats
}

\author{
Eswar Kumar Kilari, Swathi Putta, Kotaiah Silakabattini \\ Pharmacology Division, A.U. College of Pharmaceutical Sciences, Andhra University, Visakhapatnam, Andhra Pradesh, INDIA.
}

\begin{abstract}
Aim: To study the expression of Insulin Receptor (IR) in pancreas and proglucagon in the ileum homogenate with the hydroalcoholic extract of Gymnema sylvestre (HAGS) in streptozotocin induced diabetic rats. Materials and Methods: The HAGS was administered once daily at 100,200 and $400 \mathrm{mg} / \mathrm{kg}$ bd.wt for 28 days to STZ induced diabetic rats. Blood samples were collected at the end of 28 days. Serum blood glucose, glycosylated hemoglobin ( $\mathrm{HbA}_{1 \mathrm{c}}$ ), insulin levels; SOD (Superoxide Dismutase), CAT (Catalase), MDA (Malondialdehyde) were estimated in the pancreatic and liver homogenates and the expression of pancreatic Insulin Receptor (IR) and intestinal proglucagon were estimated at the end of 28 days treatment period in all the treatment groups. Results: The HAGS showed a significant reduction in the serum levels of glucose and $\mathrm{HbA}_{1 \mathrm{c}}$ with elevated insulin levels in diabetic rats. The HAGS showed a significant reduction in MDA with elevated levels of SOD and CAT in the pancreatic and liver homogenates. The expression levels of pancreatic Insulin Receptor (IR) and intestinal proglucagon were increased significantly with HAGS in diabetic rats. Conclusion: It is concluded that HAGS has significant antihyperglycemic activity through stimulation of GLP-1 release and its enhanced proglucagon expression in ileum followed by Insulin Receptor (IR) expression in pancreas. This may be due to the presence of active principles like saponins, triterpenoids and anthraquinones in Gymnema sylvestre.

Key words: Diabetes, Gymnema sylvestre, Proglucagon, Insulin, GLP-1, Insulin Receptor.
\end{abstract}

\section{INTRODUCTION}

The diabetes is a chronic metabolic progressive disease with hyperglycemia or insulin resistance or both. ${ }^{1}$ People at the age between 20 to 79 years were prone to diabetes and it was reported that 382 million diabetics were reported among 219 countries in the world and was estimated to increase upto 592 million in 2035. ${ }^{2}$ The uncontrolled hyperglycemia that tends to the development of microvascular and macrovascular complications might be due to the oxidative stress, polyol pathway, hexosamine pathway, formation of advance glycation end products and also due to incretin effect. ${ }^{3}$

The insulin secretion was stimulated by the incretin hormones, which are produced from the gastrointestinal tract in response to nutrients entry. ${ }^{4}$ Glucose Insulinotropic
Peptide (GIP) and Glucagon like peptide-1 (GLP-1) are the two major gut peptides belongs to the incretin family. The GLP-1 majorly is involved in the insulin stimulation ${ }^{5}$ and also inhibits the motility ${ }^{6}$ of gastrointestinal tract and appetite due to its highest insulinotropic action. These actions of GLP-1 were found to be disturbed in diabetic patients. ${ }^{7}$ Hence, there is a need to identify a potential neutraceutical compound to target and modulate the actions of GLP-1 in the management of type 2 diabetes. There are several GLP-1 analogues available in the market such as exenatide and liraglutide, but chronic use of these analogues may produces several unwanted effects such as
Submission Date: 17-07-2019; Revision Date: 05-11-2019; Accepted Date: 12-05-2020

DOI: 10.5530/ijper.54.2s.84 Correspondence: Dr. Kilari Eswar Kumar Associate Professor, A.U. College of Pharmaceutical Sciences, Andhra University, Visakhapatnam-530003, Andhra Pradesh, INDIA. Phone: +91 9440632728 E-mail: ekilari@gmail.com

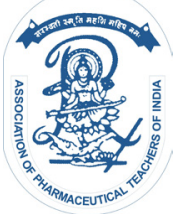

www.ijper.org 
pancreatitis, renal failure, thyroid tumors and GI disturbances such as nausea, diarrhoea, etc. ${ }^{8}$

The usage of herbal drugs and herbal based products were found to be increased due to their action on various biochemical pathways involved to alleviate the diabetes and associated complications based on their phytochemical constituents. ${ }^{9}$ Now a days, potential use of herbal drugs was found to be benefited over the use of allopathic medications due to their fewer side effects. The leaves of Gurmar (Gymnema sylvestre), Asclepediaceae popularly called as sugar destroyer. The leaves of gurmar is a rich source of alkaloids, anthraquinone glycosides, flavanoids, gymnemic acids, tartaric acid, formic acid, butyric acid, phytin, resin, Lupenol, stigmasterol ${ }^{10,11}$ and calcium oxalate. ${ }^{12}$ It poses a wide range of pharmacological properties as control over frequent urination, ${ }^{13}$ stomach stimulation, anti-diabetic, ${ }^{14,15}$ anti-ulcer, antiinflammatory and antioxidant properties. ${ }^{16}$ Hence the present work was undertaken with the objective of studying the effect of Gymnema sylvestre for antidiabetic, antioxidant, intestinal proglucagon and pancreatic insulin receptor gene expression levels in STZ induced diabetic rats.

\section{MATERIALS AND METHODS \\ Plant extract}

The aqueous stem extract of Gymnema sylvestre was obtained from Lalia Impex, Vijayawada.

\section{Chemicals and drugs}

2, 2-diphenyl-1-picrylhydrazyl (DPPH) was purchased from Sigma Chemical Co. (St.Louis, MO, USA). TRIzol reagent was purchased from GeNei, Bangalore, India. Taq DNA polymerase was acquired from Invitrogen (Carlsbad, CA, USA). Sitagliptin was purchased from Himedia chemicals. The remaining kits and chemicals used are of analytical grade.

\section{In vitro antioxidant activities}

The HAGS extract tested for DPPH radical scavenging potency according to the method Liu and Zaho, 2006. ${ }^{17}$ The hydrogen peroxide scavenging assay was estimated using the method reported by Ruch et al. 1989. ${ }^{18}$ According to Winter bourn $1984,{ }^{19}$ hydroxyl radical scavenging activity was calculated. Scavenging activity of superoxide anion radical was determined by the method of Beauchamp, $1971 .{ }^{20}$ nitric oxide scavenging activity was calculated according to the method of Marcocci, 1994. ${ }^{21}$ reducing power of the extracts was determined by the method of Oyaizu, 1986. ${ }^{22}$

\section{Acute toxicity studies}

The acute toxicity studies are conducted according to the OCED 423 guidelines. Adult albino mice of either sex were used and starved overnight. The HAGS extracts was tested at $2000 \mathrm{mg} . \mathrm{kg}$ b.wt. ${ }^{23}$ The behavioral, neurological and autonomic profile, toxicity and mortality were observed upto $72 \mathrm{hrs}$.

\section{Animals}

Adult male Wistar rats $(180 \pm 10 \mathrm{~g})$ were purchased from Mahaveer Enterprises, Hyderabad, India. All the animals are maintained under the standard temperature $\left(23 \pm 2^{\circ} \mathrm{C}\right), 50 \%$ of humidity and 12:12 hrs light and dark cycles. The standard pellet diet with Carbohydrates (48.8gm), Protein (21 gm), Fat (3gm), Calcium (0.8gm), Phosphorous (0.4gm), Fiber (5gm), Moisture (13g) and Ash (8gm) was obtained from Rayon's Biotech Pvt Ltd, India and at ad libitum water. The animal house had CPCSEA (Regd. No.516/01/A/CPCSEA) approval and the work was approved by the Institutional animal ethics committee (IAEC-19/AU-Pharm/2017-18).

\section{Experimental design}

After acclimatization period all the animals are divided into 6 groups and with 6 rats of each group. The animals are under $16 \mathrm{hrs}$ deprived before the experimentation. The fasting blood glucose levels were estimated before starting the experiment. Group 1 received vehicle, group 2 a single dose of STZ (60 mg/kg b.wt) and dissolved in citrate buffer, group 3 received $1.0 \mathrm{ml}$ of sitagliptin $(5 \mathrm{mg} / \mathrm{kg})$, group 4 treated with HAGS $(100 \mathrm{mg} / \mathrm{kg})$, group 5 treated with HAGS $(200 \mathrm{mg} / \mathrm{kg})$ and group 6 treated HAGS (400 $\mathrm{mg} / \mathrm{kg}$ ) once daily by oral administration in STZ induced diabetic rats. Blood was collected using retro orbital plexus to estimate serum biochemical parameters. All the animals were anaesthetized using ether anesthesia prior to scarification by cervical dislocation method at the end of 28 days.

\section{Biochemical Estimation}

At the end of 28 days the serum blood glucose levels, $\mathrm{HbA}_{1 \mathrm{c}}$ and insulin levels were estimated. ${ }^{24}$ The pancreas was isolated and prepared 10\% homogenate using $10 \mathrm{mM}$ Tris hydrochloride buffer using tissue homogenizer and centrifuged at 12000rpm for $15 \mathrm{~min}$ at $0^{\circ} \mathrm{C}$ using cooling centrifuge (R-247, Refrigerated Centrifuge, Mumbai, India). The tissue parameters such as protein, ${ }^{25}$ lipid peroxidation (LPO) ${ }^{26}$ Superoxide dismutase $(\mathrm{SOD})^{27}$ and Catalase $(\mathrm{CAT})^{28}$ were estimated in all the treatment groups.

Total RNA extraction and reverse transcription and polymerase chain reaction 
Total RNA was isolated from intestinal samples using TRIzol reagent (GeNei, Bangalore, India) according to manufacture's instructions. The RNA concentration was measured at $260 \mathrm{~nm}$ with UV spectrophotometer (UV-1800 UV-Vis Spectrophotometer, Japan). The RNA pellet was dissolved in diethylpyrocarbonate (DPEC) treated water. The cDNA was synthesized using $9 \mu \mathrm{L}$ of total RNA and reverse transcriptase purchased from Invitrogen, Carlsbad, USA. The PCR studies were conducted by using thermal cycler PCR Machine (Model No.LT- 240) using Taq DNA polymerase with the following thermal cycle profiling: initial denaturation at $95^{\circ} \mathrm{C}$ for $5 \mathrm{~min}$ followed by 30 cycles (Denaturation at $95^{\circ} \mathrm{C}$ for $5 \mathrm{~min}$, annealing at $60^{\circ} \mathrm{C}$ for $30 \mathrm{Sec}$, denaturation at $72^{\circ} \mathrm{C}$ for $30 \mathrm{Sec}$ and extension at $72^{\circ} \mathrm{C}$ for $10 \mathrm{~min}$ ).

The following primer sets were used to amplify proglucagon and insulin gene expression. All the primers were ordered from GeNei, Bangalore, India.

\section{Proglucagon}

Forward:PLG-F_R:GTAATGCTGGTACAAGGCAG Reverse: PLG-R_R: TTGATGAAGTCTCTGGTGGCA

\section{Insulin}

Forward: INSULIN-F_384: CCCTAAGTGACCAGCTACA

Reverse: INSULIN-R_384: TTGCAGTAGTTCTCCAGTTG

\section{RESULTS}

\section{The Effect of HAGS on in vitro anti-oxidant activity}

The HAGS showed a significant in vitro antioxidant activity (Table 1). The various concentrations of HAGS showed dependent radical scavenging activity. The $\mathrm{IC}_{50}$ values of HAGS for scavenging of DPPH, hydrogen peroxide, nitric oxide, reducing power, phosphomolybdinum and hydroxyl radical scavenging activity of HAGS extract showed significant scavenging activity compared to the ascorbic acid.

\section{The Effect of HAGS on blood glucose, $\mathrm{HbA}_{1 \mathrm{c}}$ and insulin}

STZ induced diabetic rats showed significant increase in blood glucose and $\mathrm{HbA}_{1 \mathrm{c}}$ levels when compared with controls (Table 2). Whereas HAGS and sitagliptin treated diabetic rats showed a significant decrease in blood glucose and $\mathrm{HbA}_{1 \mathrm{c}}$ levels. In diabetic rats, insulin levels were significantly $(p<0.05)$ decreased when compared to normal rats. Whereas in HAGS treated

\begin{tabular}{|c|c|c|}
\hline \multirow{3}{*}{ Table 1: Effect of HAGS on in vitro antioxidant } \\
activity. \\
\hline $\begin{array}{c}\text { In vitro Antioxidant } \\
\text { Activity }\end{array}$ & \multicolumn{2}{|c|}{ IC $_{50}(\boldsymbol{\mu g})$} \\
\cline { 2 - 3 } & Ascorbic acid & HAGS \\
\hline DPPH radical & $22.65 \pm 1.0$ & $38.47 \pm 0.8$ \\
\hline $\mathrm{H}_{2} \mathrm{O}_{2}$ radical & $02.59 \pm 0.9$ & $02.68 \pm 1.3$ \\
\hline Nitric Oxide radical & $265.71 \pm 1.9$ & $495.4 \pm 0.5$ \\
\hline Reducing Power & $16.82 \pm 0.8$ & $07.39 \pm 0.8$ \\
\hline Phosphomolybdenum & $61.34 \pm 0.5$ & $112.3 \pm 1.0$ \\
\hline Hydroxyl radical & $301.32 \pm 1.2$ & $272.6 \pm 1.3$ \\
\hline
\end{tabular}

Values are expressed as mean $\pm \mathrm{SEM} ; n=3$

\begin{tabular}{|c|c|c|c|}
\hline \multicolumn{3}{|c|}{$\begin{array}{c}\text { Table 2: Effect of HAGS of blood glucose, \%HbA } \\
\text { and insulin levels in STZ induced diabetic rats. }\end{array}$} \\
\hline Groups & $\begin{array}{c}\text { Blood } \\
\text { Glucose } \\
\text { (mg/dL) }\end{array}$ & $\% H b A 1 c$ & $\begin{array}{c}\text { Insulin } \\
\text { (ulU/ml) }\end{array}$ \\
\hline Normal & $88.05 \pm 1.8^{*}$ & $2.89 \pm 0.10^{*}$ & $4.86 \pm 0.22^{*}$ \\
\hline Diabetic control & $366.2 \pm 6.5$ & $10.12 \pm 0.33$ & $3.29 \pm 0.89$ \\
\hline Standard & $95.1 \pm 3.5^{*}$ & $3.55 \pm 0.23^{*}$ & $4.65 \pm 0.45^{*}$ \\
\hline HAGS(100mg/kg) & $125.9 \pm 3.0^{*}$ & $7.23 \pm 0.22^{*}$ & $3.96 \pm 0.89^{*}$ \\
\hline HAGS(200mg/kg) & $102.4 \pm 2.8^{*}$ & $5.31 \pm 0.11^{*}$ & $4.54 \pm 0.76^{*}$ \\
\hline HAGS(400mg/kg) & $93.23 \pm 5.7^{*}$ & $3.77 \pm 0.18^{*}$ & $4.88 \pm 0.77^{*}$ \\
\hline
\end{tabular}

$P<0.05^{*}$ significance followed by two way ANOVA followed by Bonferroni's post test when compared with toxicant group.

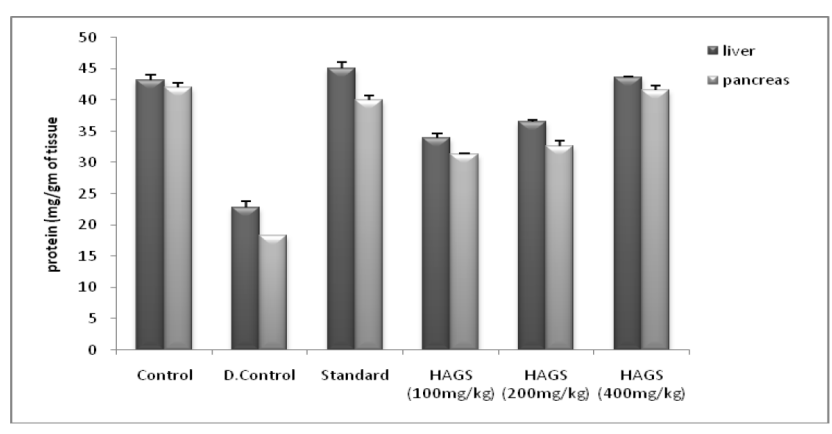

Figure 1: Effect of HAGS on protein levels in liver and pancreas of STZ induced diabetic rats.

Values are expressed as mean $\pm S E M$; $n=6$

diabetic rats, insulin levels were significantly $(p<0.05)$ increased when compared to diabetic rats.

The Effect of HAGS on protein, Malionaldehyde (MDA) and antioxidant enzyme levels in pancreas and liver

Total protein levels were found to be decreased in diabetic liver and pancreas whereas treatment with HAGS showed increased levels of protein levels significantly at $p<0.05$ (Figure 1). Antioxidant enzymes like SOD and catalase levels were significantly $(p<0.05)$ decrease in both pancreas and liver of diabetic rats. Furthermore, HAGS extract and Sitagliptin treatment 
elevated the levels of SOD, CAT when compared to diabetic rats at $\mathrm{p}<0.05$ (Figure 2, 3). The MDA contents were significantly $(p<0.05)$ increased in both of the pancreas and liver of diabetic rats and with HAGS treatment showed a significant reduction of MDA when compared to control induced rats. However, HAGS and Sitagliptin treated diabetic rats showed a significant $(p<0.05)$ decline in MDA contents when compared to the diabetic rats (Figure 4).

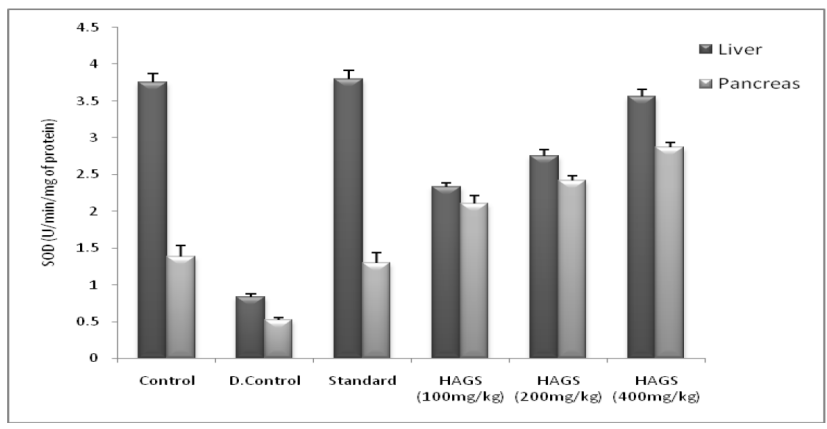

Figure 2: Effect of HAGS on SOD levels in liver and pancreas of STZ induced diabetic rats.

Values are expressed as mean \pm SEM; $n=6$

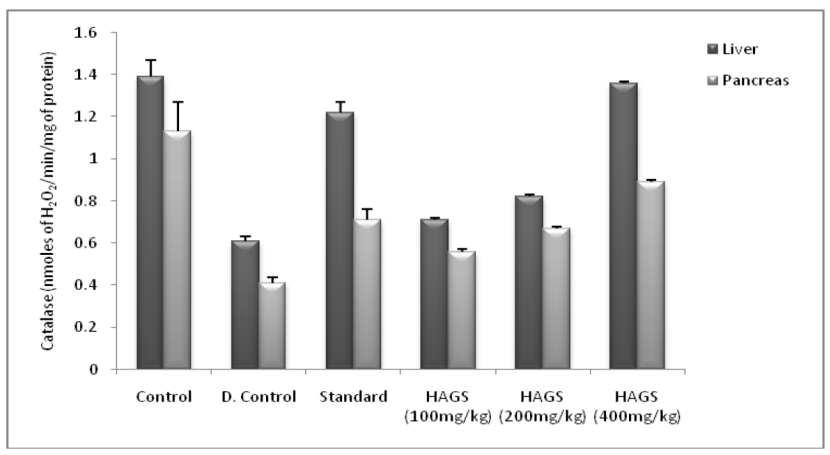

Figure 3: Effect of HAGS on CAT levels in liver and pancreas of STZ induced diabetic rats.

Values are expressed as mean \pm SEM; $n=6$

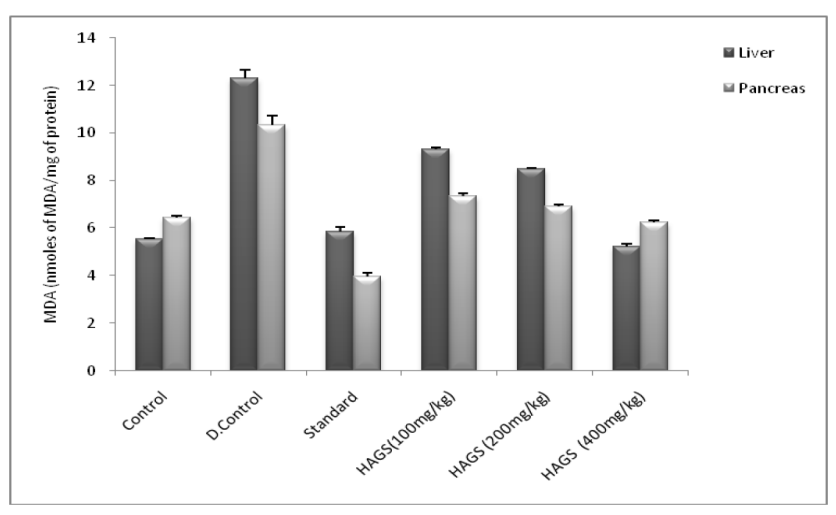

Figure 4: Effect of HAGS on MDA levels in liver and pancreas of STZ induced diabetic rats.

Values are expressed as mean \pm SEM; $n=6$

\section{The Effect of HAGS on intestinal proglucagon and pancreatic insulin gene expression levels}

The pancreatic insulin gene expression levels were significantly $(\phi<0.05)$ decreased in diabetic rats when compared to control rats (Figure 5). However, in HAGS and sitagliptin treated diabetic rats insulin gene expression levels and expression fold change were significantly $(p<0.05)$ increased when compared with diabetic rats (Figure 6, Figure 7). Figure 8 showed the

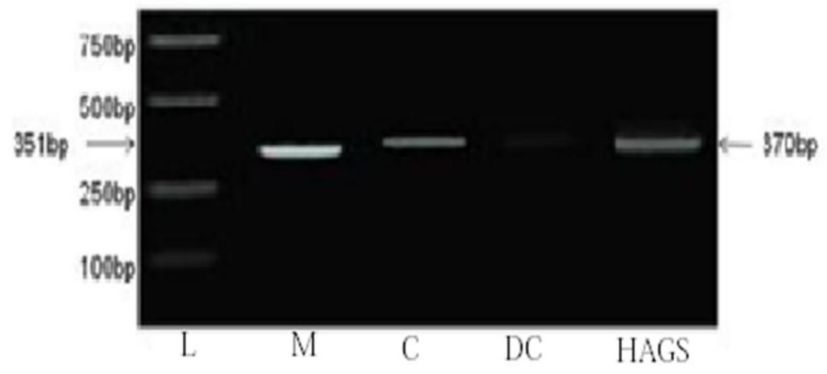

L-Ladder; M-Marker.GADPH; C:Normal; DC-Diabetic Control; HAGS-HAGS $(400 \mathrm{mg} / \mathrm{kg})$

Figure 5: Effect of HAGS on insulin gene expression in pancreas of STZ induced diabetic rats by using RT-PCR. Values are expressed as mean $\pm \mathrm{SEM} ; n=6$

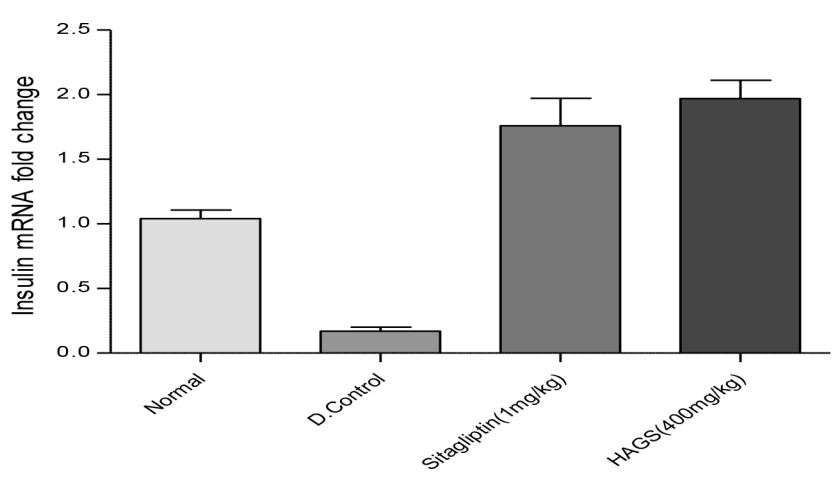

Figure 6: Effect of HAGS on percentage fold change of insulin expression.

Values are expressed as mean \pm SEM; $n=6$

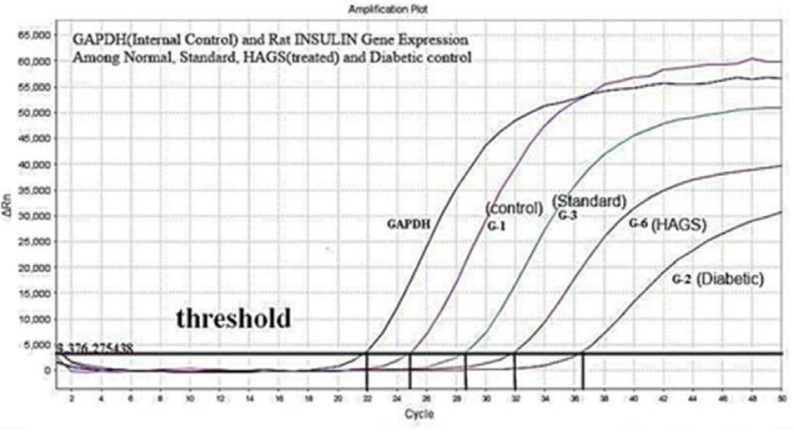

Figure 7: Effect of HAGS on insulin gene expression fold change in pancreas of STZ induced diabetic rats. Values are expressed as mean $\pm S E M ; n=6$ 
STZ induced diabetic rats showed a significant $(p<0.05)$ decrease in intestinal proglucagon gene expression levels in comparison to control rats, whereas, in HAGS and sitagliptin treated diabetic rats, the proglucagon gene expression levels and fold change were significantly increased (Figure 9, Figure 10) when compared with the diabetic rats.

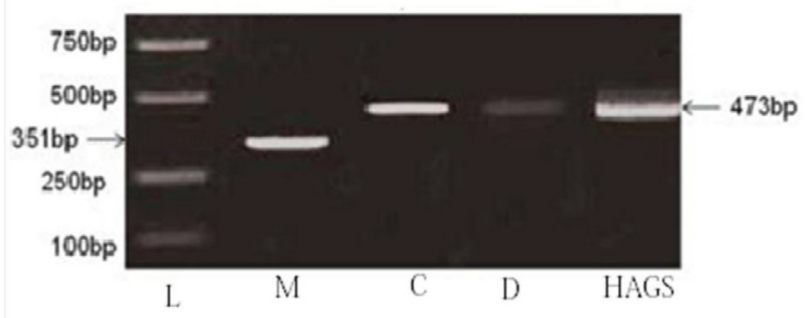

L-Ladder; M-Marker GADPH; C-Control; DC-Diabetic Control; HAGS-HAGS $(400 \mathrm{mg} / \mathrm{kg})$

Figure 8: Effect of HAGS on Proglucagon gene expression in ileum of STZ induced diabetic rats by using RT-PCR. Values are expressed as mean $\pm S E M ; n=6$

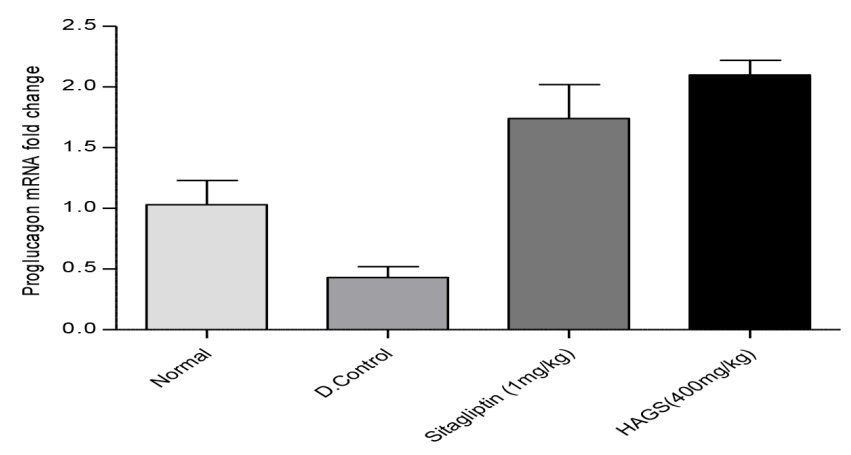

Figure 9: Effect of HAGS on percentage fold change of proglucagon expression.

Values are expressed as mean \pm SEM; $n=6$

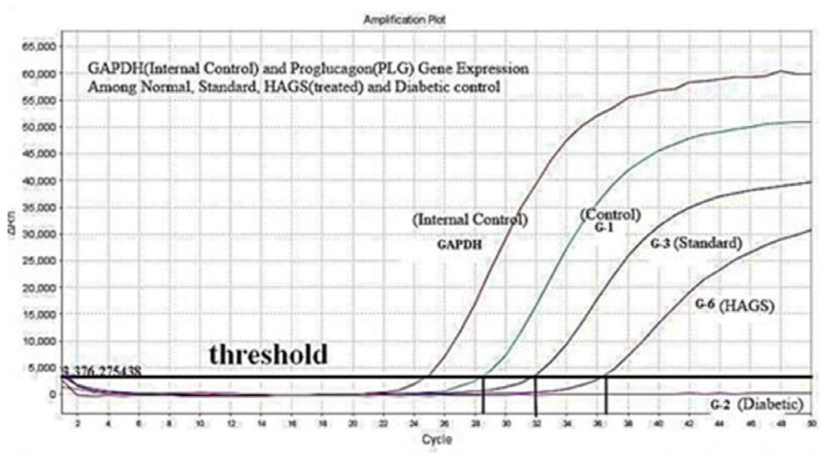

Figure 10: Effect of HAGS on proglucagon gene expression fold change in ileum of STZ induced diabetic rats. Values are expressed as mean $\pm S E M ; n=6$

\section{DISCUSSION}

Free radicals are the major cause of oxidative stress. The imbalance between the free radicals and antioxidant defense system lead to the alteration of antioxidant potential tend to the development of diabetes mellitus and other chronic metabolic dysfunctions. ${ }^{29}$ Hyperglycemia itself also causes production of oxygen free radicals and their by the end products. The HAGS extract possesses significant antioxidant activity in various in vitro models, it may be due to the electron or hydrogen donating capability of HAGS and they can stabilize or terminate the free radical chain reactions. In the present study HAGS extract shows significant in vitro antioxidant activity against hydroxyl, hydrogen peroxide, nitric oxide and DPPH radicals compared to ascorbic acid. The free radical induced diabetes was achieved by using Streptozotocin due to the cytotoxic effect on pancreatic $\beta$-cells. ${ }^{30}$ The STZ alkylates the pancreatic DNA; thereby it produces reduced insulin levels, altered glucose metabolism and utilization. ${ }^{31}$ The STZ also causes stimulation of nitric oxide free radicals and initiates DNA strand break of $\beta$ cells of pancreas. $^{32}$ In STZ induced diabetic rats were elevated blood glucose levels but in the treatment with HAGS there was a significant reduction in elevated blood glucose levels. The glucose upon irreversible condensation with the hemoglobin at the $\mathrm{N}$ terminal chain tends to the formation of Glycosylated hemoglobin $\left(\mathrm{HbA}_{1 \mathrm{c}}\right) .^{33}$ The levels of $\mathrm{HbA}_{1 \mathrm{c}}$ were found to be elevated in STZ induced rats and reverted to normal range after treatment with HAGS extract. It indicates that protective activity of HAGS from hyperglycemia might be reason to the improvement in insulin secretion. In the present study in STZ induced diabetic rats, MDA content was increased. Treatment with HAGS extract for 28 days significantly reduced the pancreatic MDA content indicating a protective role of extract; this may be attributed to the presence of phytochemicals such as alkaloids, glycosides and steroids. Many of antioxidant principles reported to have inhibitory action on MDA levels. ${ }^{34}$ Antioxidant defense system provides the body to fight against free radicals. The SOD acts by reducing the conversion of superoxide into hydrogen peroxide. ${ }^{35}$ In diabetic condition, the levels of SOD are found to be diminished and could result to excessive formation of $\mathrm{H}_{2} \mathrm{O}_{2}$. The SOD was found to be glycosylated during diabetes. ${ }^{36}$ The CAT is an enzyme playing a role in elimination of $\mathrm{H}_{2} \mathrm{O}_{2}{ }^{37}$ Both the SOD and CAT were found to be decreased in STZ induced diabetic rats. Treatment with HAGS showed a significant elevation of SOD and CAT that might be due to its antioxidant 
activity as they have hydroxyl radical and $\mathrm{H}_{2} \mathrm{O}_{2}$ scavenging activity as discussed. The HAGS extract treated diabetic rats pancreatic antioxidant enzymes were significantly increased which could be attributable to strong anti-oxidative properties. ${ }^{38}$

The prohormone convertase 2 (PC2) enzymes breaksdown the proglucagon into glucagon in pancreatic $\alpha$ cells and the prohormone convertase 1 are involved in the conversion of proglucagon into GLP-1 in intestinal L- cells. Hence, the present study aimed to identify the mechanism of proglucagon in stimulating the GLP-1 in ileum and its effect on insulin secretion and insulin expression in pancreas as reported earlier by Whalley NM, 2011. ${ }^{39}$ As mentioned above, STZ induced diabetes resulted to enhanced generation of GLP-1 with Gymnema sylvestre treatment. The activity might be due to the presence of gymnemic acid present in the HAGS as reported earlier by Nakamura et al. $1999^{40}$ to increased insulin secretion, increased utilization of glucose and inhibition of glucose absorption from intestine.

There was a significant reduction of proglucagon expression in STZ induced diabetic rats when compared with the normal control rats. The treatment with HAGS was found to increase the expression of proglucagon in intestinal homogenate in diabetic rats. This might be the key mechanism in increased release of insulin from pancreatic $\beta$ cells. Further the HAGS also found to increase the expression of Insulin Receptor (IR) gene in pancreatic $\beta$ cells, which might be responsible for antihyperglycemic activity. The present study proves the herbal drug induced antihyperglycemic activity.

\section{CONCLUSION}

The significant antihyperglycemic activity through its activity on stimulation of GLP-1 release and its enhanced proglucagon expression in ileum followed by insulin receptor (IR) expression in pancreas. This may be due the presence of active principles like saponins, triterpenoids and anthraquinones in Gymnema sylvestre.

\section{ACKNOWLEDGEMENT}

The authors acknowledge the financial support from AICTE-RPS New Delhi [Grant No. Ref. No: 1. F.No: A.V (3)/ AICTE-RPS/ 2014].

\section{CONFLICT OF INTEREST}

Authors do not have any conflict of interest.

\section{ABBREVIATIONS}

IR: Insulin Receptor; GLP-1: Glucagon like peptide-1; GIP: Glucose Insulinotropic Peptide; STZ: Streptozotocin; SOD: Superoxide dismutase; CAT: Catalase; TBA: Thiobarbituric Acid; NO: Nitric oxide; PC2: Prohormone Convertase -2 .

\section{REFERENCES}

1. Putta S, Yarla NS, Kumar KE, Lakkappa DB, Kamal MA, Scotti L, et al. Preventive and Therapeutic Potentials of Anthocyanins in Diabetes and Associated Complications. Curr Med Chem. 2018;25(39):5347-71.

2. Guariguata L, Whiting DR, Hambleton I, Beagley J, Linnenkamp U, Shaw JE, et al. Global estimates of diabetes prevalence for 2013 and projections for 2035. Diabetes Res Clin Pract. 2014;103(2):137-49.

3. Marcovecchio ML, Lucantoni M, Chiarelli F. Role of chronic and acute hyperglycemia in the development of diabetes complications. Diabetes Technology and Therapeutics. 2011;13(3):389-94.

4. MacDonald PE, El-Kholy W, Riedel MJ, Salapatek AM, Light PE, Wheeler MB. The multiple actions of GLP-1 on the process of glucose-stimulated insulin secretion. Diabetes. 2002;51(Suppl 3):S434-42.

5. Orskov C, Holst JJ, Nielsen OV. Effect of truncated glucagon-like peptide-1 [proglucagon-(78-107) amide] on endocrine secretion from pig pancreas, antrum and nonantral stomach. Endocrinology. 1988;123(4):2009-13.

6. Wettergren A, Schjoldager B, Mortensen PE, Myhre J, Christiansen J, Holst JJ. Truncated GLP-1 (proglucagon 78-107-amide) inhibits gastric and pancreatic functions in man. Digestive Diseases and Sciences. 1993;38(4):665-73.

7. Layer P, Holst JJ, Grandt D, Goebell H. Ileal release of glucagon-like peptide-1 (GLP-1). Association with inhibition of gastric acid secretion in humans. Digestive Diseases and Sciences. 1995;40(5):1074-82.

8. Gupta V. Glucagon-like peptide-1 analogues: An overview. Indian J Endocrinol Metab. 2013;17(3):413-21.

9. Kar A, Choudhary BK, Bandyopadhyay NG. Comparative evaluation of hypoglycaemic activity of some Indian medicinal plants in alloxan diabetic rats. J Ethnopharmacol. 2003;84(1):105-8.

10. Kanetkar P, Singhal R, Kamat M. Gymnema sylvestre: A Memoir. J Clin Biochem Nutr. 2007;41(2):77-81.

11. Yen DTH, Toan NV, Tai BH, Yen PH, Nhiem NX, Kiem V, etal. Oleananesaponins from Gymnema sylvestre. Phytochemistry. 2019;57(1):39-45.

12. Sinsheimer JE, Subba RG, Mcllhenny HM. Constituents from Gymnema sylvestre Leaves $\mathrm{V}$ : Isolation and Preliminary Characterization of the Gymnemic Acids. Journal of Pharmaceutical Sciences. 1970;59(5):622-8.

13. Evans WC. Trease and evans' pharmacognosy E-book: Elsevier Health Sciences. Amsterdam, Netherlands. 2009.

14. Daisy P, Eliza J, Farook KA. A novel dihydroxy gymnemic triacetate isolated from Gymnema sylvestre possessing normoglycemic and hypolipidemic activity on STZ-induced diabetic rats. Journal of Ethnopharmacology. 2009;126(2):339-44.

15. Ramkumar KM, Ponmanickam P, Velayuthaprabhu S, Archunan G, Rajaguru PJF, Toxicology C. Protective effect of Gymnema montanum against renal damage in experimental diabetic rats. Food Chem Toxicol. 2009;47(10):2516-21.

16. Koch TR, Yuan LX, Stryker SJ, Ratliff P, Telford GL, Opara EC, et al. Total antioxidant capacity of colon in patients with chronic ulcerative colitis. Dig Dis Sci. 2000;45(9):1814-9.

17. Mouming LX, Industries F. Antioxidant Activities and Functional Composition Content of Selected Phyllanthus emblica L. Fruits Juice [J]. Food and Fermentation Industries. 2006;5.

18. Ruch RJ, Cheng SJ, Klaunig JEJC. Prevention of cytotoxicity and inhibition of intercellular communication by antioxidant catechins isolated from Chinese green tea. Carcinogenesis.1989;10(6):1003-8.

19. Winterbourn CC, Button HC. Hydroxyl radical production from hydrogen peroxide and enzymatically generated paraquat radicals: Catalytic requirements and oxygen dependence. Archives of Biochemistry and Biophysics. 1984;235(1):116-26. 
20. Beauchamp C, Fridovich I. Superoxide dismutase: Improved assays and an assay applicable to acrylamide gels. Analytical Biochemistry. 1971;44(1):276-87.

21. Marcocci L, Maguire JJ, Droylefaix MT, Packer L. The nitric oxide-scavenging properties of Ginkgo biloba extract EGb 761. Biochemical and Biophysical Research Communications. 1994;201(2):748-55.

22. Oyaizu M. Studies on Products of Browning Reaction Antioxidative Activities of Products of Browning Reaction Prepared from Glucosamine. The Japanese Journal of Nutrition and Dietetics. 1986;44(6):307-15.

23. Patel C, Dadhaniya P, Hingorani L, Soni MG. Safety assessment of pomegranate fruit extract: Acute and Subchronic Toxicity Studies. Food and Chemical Toxicology: An International Journal Published for the British Industrial Biological Research Association. 2008;46(8):2728-35.

24. Trinder P. Determination of glucose in blood using glucose oxidase with an alternative oxygen acceptor. Annals of Clinical Biochemistry. 1969;6(1):24-7.

25. Lowry OH, Rosebrough NJ, Farr AL, Randall RJJJobc. Protein measurement with the Folin phenol reagent. Journal of Biological Chemistry. 1951;193:265-75.

26. Ohkawa H, Ohishi N, Yagi K. Assay for lipid peroxides in animal tissues by thiobarbituric acid reaction. Analytical Biochemistry.1979;95(2):351-8.

27. Misra HP, Fridovich I. The role of superoxide anion in the autoxidation of epinephrine and a simple assay for superoxide dismutase. Journal of Biological Chemistry. 1972;247(10):3170-5.

28. Maehly A, Chance B. Catalases and peroxidases. Methods Biochem Anal. 1954;1:357-424.

29. Maritim AC, Sanders A, Watkins lii JB. Diabetes, oxidative stress and antioxidants: A review. Journal of Biochemical and Molecular Toxicology. 2003;17(1):24-38.

30. Kumar GPS, Arulselvan P, Kumar DS, Subramanian SP. Anti-diabetic activity of fruits of Terminalia chebula on streptozotocin induced diabetic rats. Journal of Health Science. 2006;52(3):283-91.

31. Arumugam S, Kavimani S, Kadalmani B, Ahmed ABA, Akbarsha MA, Rao MV. Antidiabetic activity of leaf and callus extracts of Aegle marmelos in rabbit. Science Asia. 2015
32. Rodríguez T, Alvarez B, Busquets S, Carbó N, López-Soriano FJ, Argilés JMJB, et al. The increased skeletal muscle protein turnover of the streptozotozin diabetic rat is associated with high concentrations of branched-chain amino acids. Biochemical and Molecular Medicine. 1997;61(1):87-94.

33. O'Hea EL, Moon S, Grothe KB, Boudreaux E, Bodenlos JS, Wallston K, et al. The interaction of locus of control, self-efficacy and outcome expectancy in relation to $\mathrm{HbA} 1 \mathrm{c}$ in medically underserved individuals with type 2 diabetes. Journal of Behavioral Medicine. 2009;32(1):106-17.

34. Bagri P, Ali M, Aeri V, Bhowmik M, Sultana S. Antidiabetic effect of Punica granatum flowers: Effect on hyperlipidemia, pancreatic cells lipid peroxidation and antioxidant enzymes in experimental diabetes. Food and Chemical Toxicology. 2009;47(1):50-4.

35. Blokhina O, Virolainen E, Fagerstedt KVJAob. Antioxidants, oxidative damage and oxygen deprivation stress: a review. Annals of Botany. 2003;91(2):179-94.

36. Ravi K, Ramachandran B, Subramanian S. Protective effect of Eugenia jambolana seed kernel on tissue antioxidants in streptozotocin-induced diabetic rats. Biological and Pharmaceutical Bulletin. 2004;27(8):1212-7.

37. Kilari EK, Putta S. Biological and Phytopharmacological Descriptions of Litchi Chinensis. Pharmacogn Rev. 2016;10(19):60-5.

38. Althunibat OY, Al-Mustafa AH, Tarawneh $\mathrm{K}$, Khleifat KM, Ridzwan BH, Qaralleh HN. Protective role of Punica granatum L. peel extract against oxidative damage in experimental diabetic rats. Process Biochemistry. 2010;45(4):581-5.

39. Whalley NM, Pritchard LE, Smith DM, White A. Processing of proglucagon to GLP-1 in pancreatic alpha-cells: Is this a paracrine mechanism enabling GLP-1 to act on beta-cells?. The Journal of Endocrinology. 2011;211(1):99-106.

40. Nakamura $\mathrm{Y}$, Tsumura $\mathrm{Y}$, Tonogai $\mathrm{Y}$, Shibata T. Fecal steroid excretion is increased in rats by oral administration of gymnemic acids contained in Gymnema sylvestre leaves. J Nutr. 1999;129(6):1214-22.

\section{SUMMARY}

Herbal medicines may be used as an alternative therapy in this condition as they are effectively used for the treatment of diabetes in Ayurveda and are generally well tolerated. Gymnema sylvestre is recommended for diabetes and several chronic diseases. The aim of the present study was to determine the effect of hydro alcoholic extract of Gymnema sylvestre (HAGS) on antihyperglycemia, in vivo antioxidant, intestinal proglucagon and pancreatic insulin gene expression levels in streptozotocin induced diabetic rats. The synthesis and secretion of proglucagon-derived peptides are regulated in a tissue-specific manner in pancreas and intestine. Treated groups divided into 6 groups serves as control (group 1), diabetic control (group 2), sitagliptin (group 3), HAGS100, 200 and $400 \mathrm{mg} / \mathrm{kg}$ body weight as group 4,5 and 6 respectively were administered orally once a day for 28 days. A significant increase in blood glucose and glycosylated hemoglobin $\left(\mathrm{HbA}_{1 \mathrm{c}}\right)$ with decrease serum insulin was observed in diabetic rats. Treatment with HAGS reduced the elevated levels of blood glucose and $\mathrm{HbA}_{1 \mathrm{c}}$ with significant increase in insulin in comparison with diabetic rats. At the end of the study period rats were sacrifice and tissue samples were used for further investigations. A significant reduction was observed in malondialdehyde content with elevated levels of superoxide dismutase and catalase in the pancreas and liver homogenates of diabetic rats with HAGS treatment. Pancreatic insulin and intestinal proglucagon expression levels were decreased in diabetic rats. In HAGS treated diabetic rats, the pancreatic insulin and intestinal proglucagon levels were elevated to normal levels. This indicates HAGS has protective effects on insulin and proglucagon, which is further responsible for elevated levels of GLP-1 activity. It concludes that HAGS has significant antioxidant, antihyperglycemic activity and protective activity on GLP-1. This may be due the presence of Gymnema saponins and gymnemic acids in Gymnema sylvestre. 


\section{PICTORIAL ABSTRACT}

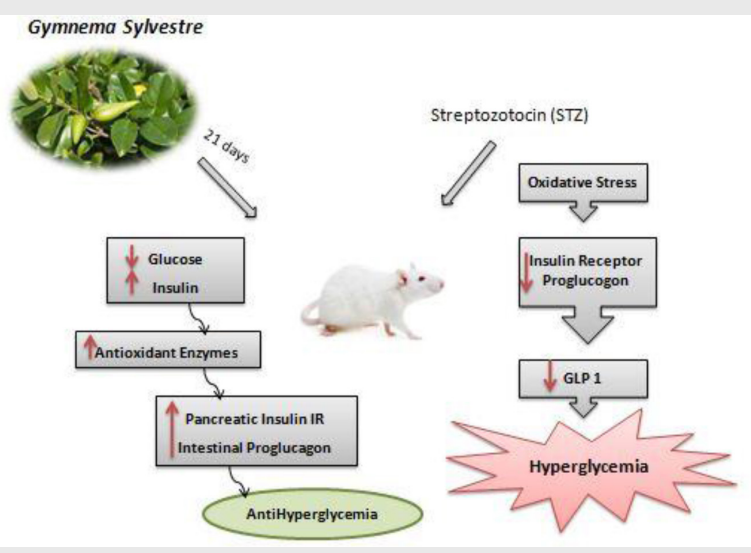

Cite this article: Kilari EK, Putta S, Silakabattini K. Effect of Gymnema sylvestre on Insulin Receptor (IR) and Proglucagon Gene Expression in Streptozotocin Induced Diabetic Rats. Indian J of Pharmaceutical Education and Research. 2020;54(2s):s277-s284. 